\title{
ANALYSIS OF E-LEARNING BASED METROLOGICAL TRAINING (ADJUNCT, BLENDED AND FULLY ONLINE)
}

\author{
Suci Ingrid Daniati \\ Wicaksono Febriantoro
}

Metrological Resources Development Centre (MRDC), Ministry of Trade, Republic of Indonesia,

Jl. Daeng Muh. Ardiwinata km 3,4 Cihanjuang, Parongpong, Bandung cie.ingrid@gmail.com

wicaksono.f@gmail.com

\begin{abstract}
Government Regulation No.11 2017 on Civil Servant Management confirmed that every government officer is entitled to competence development for at least 20 (twenty) lesson hours in 1 (one) year. Geographical factors and measuring instrument potential that are different in each region, require various types of training options that can be easily and quickly accessed by metrological human resources to improve their competence. The alternative is e-learning based training which consist of adjunct, blended and fully online. This study will be analyzed e-learning based metrological training. Research and development (R\&D) methods with descriptive qualitative approach is used in this study. ADDIE Framework utilized to structure the analysis. Research outcomes are as follows: e-learning instructional design apply PEDATI model to construct 4 learning setting quadrants, furthermore based on the requirement criteria and IT resources in MRDC, cloud based LMS Kelase is chosen to manage e-learning activities. Achievement of competency in metrological technical training shows the average value for cognitive competence is 80 and for psychomotor competencies is 70. Various aspects that influence the success in implementing e-learning include commitment, age of participants, mastery of technology and other routine office work. Future research can be done in the area of pre, in and post e-learning based training. Parallel to them, development of learning media such as: video, stop motion, 2D/3D animation, augmented and virtual reality need to be explored more deeply in order to support e-learning content effectively.
\end{abstract}

Keywords: competence, metrological training, e-learning

\section{INTRODUCTION}

Legal metrology resources are Civil Servants placed in the Central and District City. They are required to meet the standards according to their position. To achieve competency, development needs to be carried out according to the mandate of Government Regulation No. 11 of 2017 concerning Management of Civil Servants. Every ASN employee has the right to develop the competence of civil servants to do education and / or training. 
Competency development in the form of training can be done through classical and nonclassical training. Classical training is carried out through a face-to-face learning process in front of the class, such as training, courses, seminars, and upgrading. Non-classical training is done through e-learning, training in the workplace, distance training, civil servant and private exchanges. Until now, the development of metrological HR competencies is still carried out through classical training.

The increasing penetration of internet users in Indonesia from 88.1 million people in 2014 to 132.7 million people in 2016 (Indonesian Polling, 2016) and the number of smartphone users in Indonesia, which according to the Indonesian Poll in the APJII Survey held in November 2016 shows there are 63.1 million people / 47.6\% of Indonesian citizens who use smartphones. More specifically, based on observations from 2013 as of 2017 for participants in metrological training, it was found that the use of smartphones and the internet had become mandatory for students. Then, the PPSDK lecturers with their respective initiatives have implemented learning using information technology, especially internet media in the teaching and learning process, but this has not been formalized and well structured.

Diversification of metrological training through the use of non-classical training models is expected to be able to answer the challenges of increasing the competence of the Metrological HR such as geographical factors (legal metrology HR which are spread from Sabang to Merauke) and potential of specified measuring instruments that are different in each region. It's require various types of training options that can be easily and quickly accessed by metrological human resources to improve their competence.

Forms of training that are not limited to space and time are distance training. This form of training is not new in the world of education and has been widely applied to the Open University. With the choice of this in metrological training, it is expected to be able to complete the form of classical training that has been done so far. The limitations of the types of training that can be held classically and the limited quota of training participants are things that want to find a solution with a form of non-classical training, distance training.

In implementing remote training, there are many factors that need to be studied, such as the readiness of education and training managers, the readiness of education and training providers, readiness of participants and instructors and the readiness of supporting infrastructure. E-learning is one form of distance training. According to Rashty, 1999 in (Chaeruman, 2013), e-learning can be classified into three models, namely adjunct, mixed / blended, and fully online.

Based on this, we need an innovation both strategy and method and learning model to adjust to technological developments to strengthen the learning model through content enrichment and the development of educational technology (via web-based instruction, video streaming, lab simulation, audio, synchronous and asynchronous communication, etc.).

In this study, the design of e-learning will be carried out in the form of adjunct, blended learning and fully online. Learning design will be developed in the form of Training Design (RBDP), the development of online learning media and the development of the Learning Management System (LMS) model. To analyze the implementation, a simulation of RBDP will be conducted and an evaluation of the e-learning training simulation held. 


\section{LITERATURE REVIEW}

\section{E-learning}

There are several definitions of e-learning used in this study, including the following. Elearning is the delivery of learning, training or education programs using electronic means such as computers or other electronic devices such as mobile phones in various ways to provide training, education or teaching materials (Stockley, n.d.). Horton (2006) says that elearning is the use of information technology and computers to create learning experiences. Similar to that expressed by Stockley and Horton, Noirid (2007) says e-learning is fundamentally, is an educational process that utilizes information and communication technology to bridge learning and learning activities both synchronously and asynchronously.

Referring to the definitions stated above, it can be concluded that e-learning is a term that describes the use of various electronic technologies to create an optimal learning experience. The electronic technology can be in the form of computers, the internet, or intranets and other electronic technologies such as audio / radio and video / television.

Rashty (1999) cited by Noirid (2007) classifies e-learning delivery system models into 3 categories (adjunct, mixed / blended and full online) as in Figure 1 below.

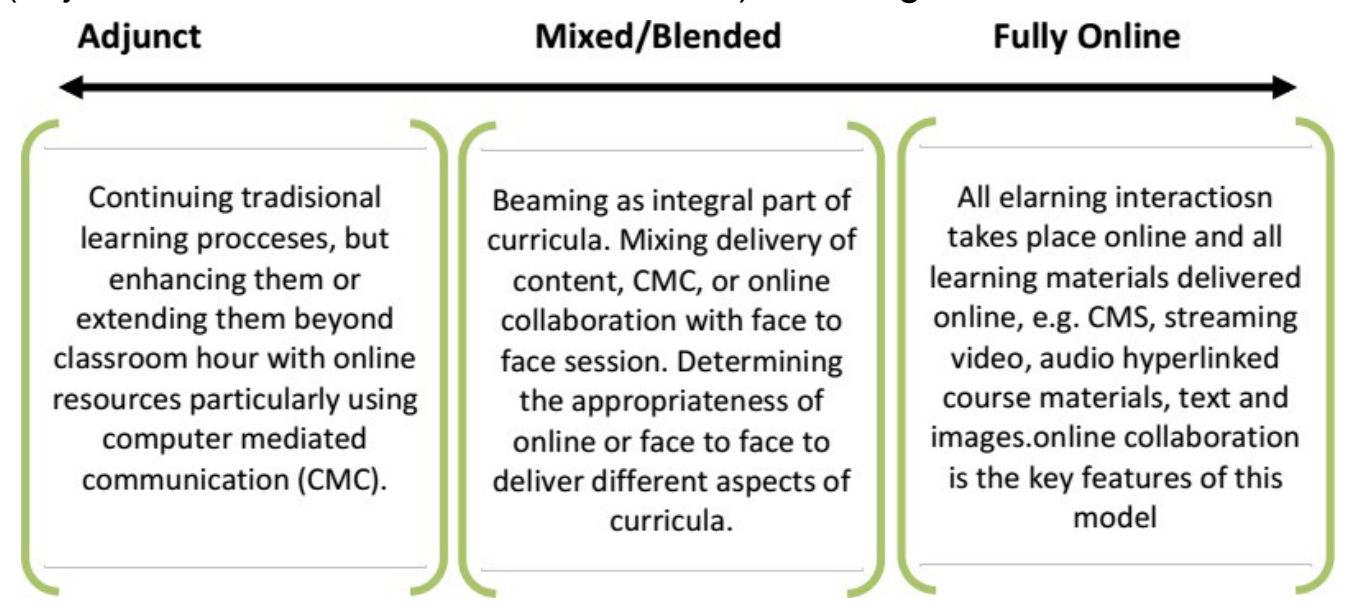

Figure 1. E-Learning Continuum Noirid (2007)

In Figure 1 can be seen there are 3 stages of e-learning, namely:

1. Adjunct: face-to-face learning (traditional) which is supported by an online delivery system as enrichment. The existence of an online system is an addition. An example to support learning in the classroom, a trainer assigns students to search for information from the internet, etc.

2. Mixed / blended: lacing the delivery system online as an integral part of the overall learning process. This means that both the face-to-face process and the online learning process are an integrative learning activities.

3. Fully Online: all learning interactions and delivery of teaching materials occur online. There is no traditional learning (face to face) at all. For example, all learning materials in the form of slides, videos uploaded and received through a Learning Management System (LMS) where students and trainer can interact in it. 


\section{E-Learning Instructional Design}

Research on blended learning design has been done quite a lot, among others by Mabed and Koehler (2012) using the concept of Taxonomy Bloom and Gagne and Alammary, Sheard and Carbone (2014) which classify blended learning design into 3 (low, medium and high impact) based on the potential changes in learning programs and student learning experiences, in Indonesia some research conducted by Prayitno (2015) which provides examples of the implementation of blended learning in primary and secondary schools.

The design of blended learning design in a more systematic way in college has been done by Chaeruman U. A. (2012), (2013) and (2017). The study used models from Kemp, Morrison, \& Ross (1994) as a rationale covering 4 components of learning design, i.e learning participants, learning objectives, learning methods and assessment of learning process. Then in the determination of learning achievement criteria using the Mager model (1984), Donald, (1999) and Dick, Carey and Carey (2005). Selection of learning settings through synchronous and asynchronous activities using a combination of Dale's cone of experience (1969), Smaldino \& Lowther (2012) learning modality and Bloom's Taxonomy (1956). This model was an improvement to existing blended learning instructional design that already implemented in Indonesia Online Learning System (SPADA). In 2017, SPADA is conducted in 6 Facilitator University along with 32 Partner University and consist of 17 subject enrolled by 1746 students (Chaeruman U. A., PEDATI Model Desain Sistem Pembelajaran Blended. Panduan Merancang Mata Kuliah Daring SPADA Indonesia, 2017). This approach is called PEDATI model which illustrated in figure 1.

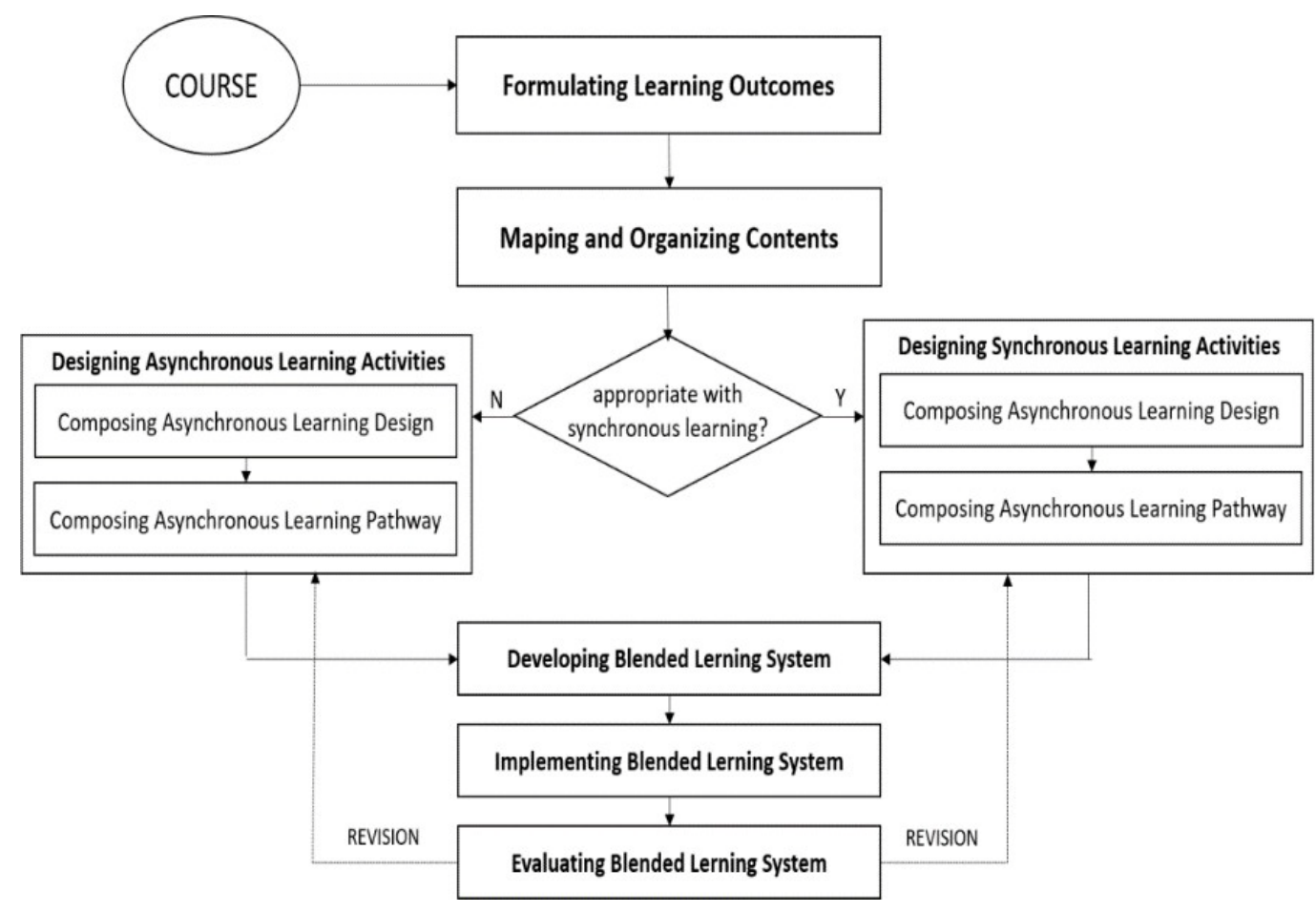

Figure 2. Blended Learning System Design

(Chaeruman, Wibawa, \& Syahrial, Blended Learning System Design Model, 2017) 
The PEDATI model in Fig. 1 is an acronym of Learning- Deepening-Applying-Evaluating or in Indonesian Pelajari-Dalami-Terapkan-Evaluasi (a cycle of learning paths offered in a blended learning system). This model was developed by Chaeruman, Wibawa, \& Syahrial (2017).

The PEDATI component consists of the following five main steps:

1. Formulate learning achievement

2. Mapping and Organizing Learning Materials

3. Choosing and Determining Synchronous and Asynchronous Learning Activities

4. Designing Asynchronous Learning Activities

5. Designing Synchronous Learning Activities

However, setting of those research mostly in colleges and schools that have the needs, learning objectives, context and characteristics of participants different from the training process in government agencies like depicted in table 1.

Table 1. Preliminary Analysis of PEDATI Model

(compiled from various sources and regulations)

\begin{tabular}{|l|l|l|}
\hline $\begin{array}{c}\text { Aspects of } \\
\text { PEDATI } \\
\text { Model }\end{array}$ & College/University & \multicolumn{1}{c|}{$\begin{array}{c}\text { Government Training } \\
\text { Center } \\
\text { (MRDC, Ministry of Trade) }\end{array}$} \\
\hline $\begin{array}{l}\text { Requirements } \\
\text { Obearning }\end{array}$ & \multicolumn{1}{c|}{$-{ }^{-}$} \\
\hline $\begin{array}{l}\text { Participants } \\
\text { Characteristic }\end{array}$ & $\begin{array}{l}\text { Students with Quite similar age } \\
\text { group 17-30 }\end{array}$ & $\begin{array}{l}\text { Government officer (ASN) } \\
\text { with Various range of age } \\
\text { from 20-50 }\end{array}$ \\
\hline Context & $\begin{array}{l}\text { Cong time learning } \\
\text { - Semester (6 month) / 16 weeks } \\
\text { - Flexible Time to learn online }\end{array}$ & $\begin{array}{l}\text { - Short Time } \\
\text { Daily-Weekly basis } \\
\text { Less Flexible Time to learn } \\
\text { online }\end{array}$ \\
\hline
\end{tabular}

From table 1 we can surmise that learning in university is different with learning in government training center seen from member attribute and learning context. Most of university student are in similar age group (17-30) while training participants in government training center have various range of age (20-50). Learning context also different, while learning in university has long term ( \pm 16 weeks), learning in government training center has shorter time (daily/weekly). University student also have more flexible time to learn comparing to government training participant that have to work from 8 a.m. to 4 p.m. every day.

\section{METHOD}

Research and development (R\&D) methods with descriptive qualitative approach are used in this study as shown in the Fig.3. Research and Development Method is a research method used to produce a particular product, and test the effectiveness of the product (Sugiyono, 
2015). The R \& D method combined with ADDIE Framework in Figure 4 are used to structure the analysis.

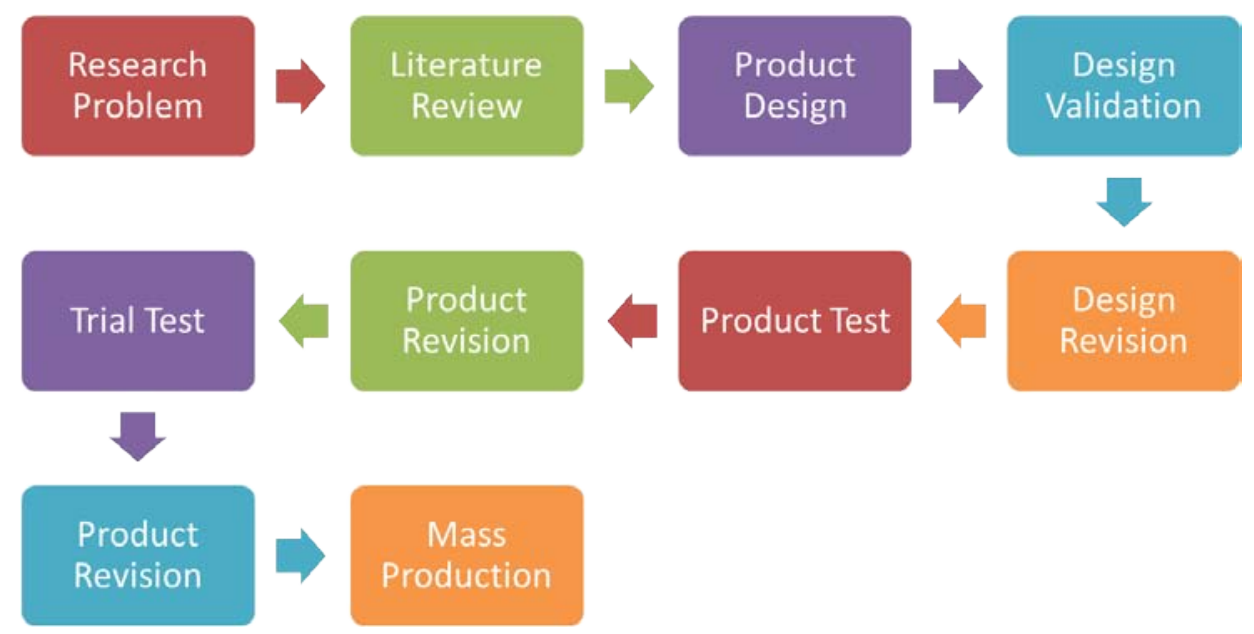

Figure 3. $R$ \& D Research Procedure (Sugiyono, 2015)

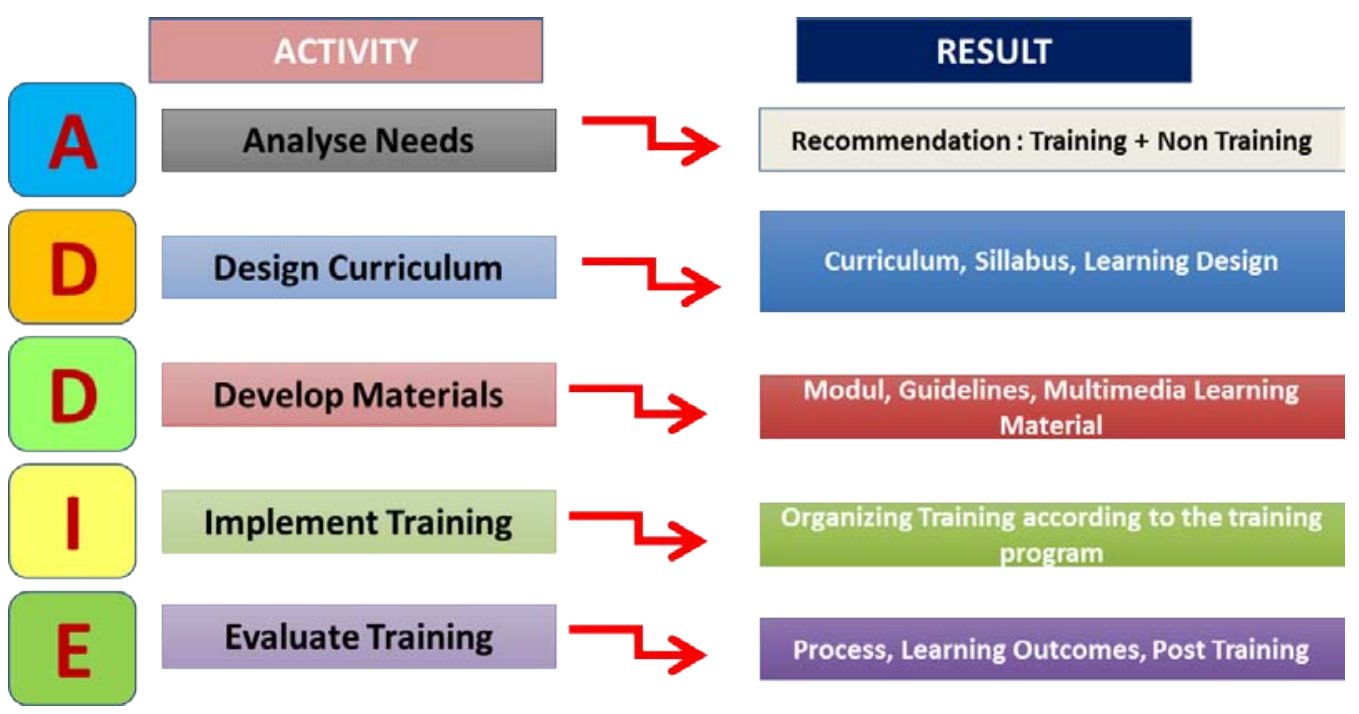

Figure 4. ADDIE Framework

In this study, as can be seen in table 2, first we conduct literature review regarding elearning instructional design. Researcher will try to map competence standard of metrological training in to PEDATI model to analyze whether it is suitable or not. After instructional design finished, validation conducted by subject matter expert through focus group discussion. Revision (if any) is made based on the design validation conducted by the experts.

The $3^{\text {rd }}$ phase is to develop learning media/material. There are several choice of learning media ranging from video tutorial, stop motion, 2D/3D Animation, and augmented and virtual reality. Video tutorial was chosen based on minimal resource needed and its characteristic to make it easier to explain procedure. The next phase is to validate those learning materials 
conducted by subject matter expert in 4 criteria (material correctness, video quality, video duration, sound quality). Revision process applied after accepting the input from subject matter expert.

The $5^{\text {th }}$ stage is to determine and choose learning management system (LMS) to help administer the learning process by information technology. First, we conduct e-learning process cycle mapping on to LMS function, and then we organize benchmarking activities in to several training institution that already implemented e-learning activities. From the benchmarking result we try to choose suitable LMS to be implemented in MRDC considering our IT resources.

The $6^{\text {th }}$ step is to implement e-learning based training that already designed in to 3 categories: adjunct, blended and fully online. Adjunct implemented in functional training, while blended and fully online applied in to technical training. Adjunct participants come from all functional training member, while blended and fully online participants are chosen based on educational background, age, and location distribution throughout Indonesia (representing all Island in Indonesia) to test particularly internet connection in each area.

The last part of the research is evaluation, we conduct 2 evaluation which is participant readiness toward e-learning and competence achievement. In training participant readiness, we evaluate through online questionnaire while competence achievement evaluated through assessment tools both online and face to face learning.

Research conducted from February until October 2018, takes place in several location such as: Bandung, Semarang, Kolaka and Samarinda with total adjunct participant: 140 students covering 9 metrological subject matters, while blended and fully online consist of 20 participants in prepackaged product and moisture meter training.

Table 2. Data Collection and Research Instrument

\begin{tabular}{|c|c|c|c|c|c|}
\hline $\begin{array}{l}N \\
0\end{array}$ & $\begin{array}{l}\text { Research } \\
\text { Phase }\end{array}$ & $\begin{array}{c}\text { Data/Informatio } \\
\mathbf{n} \\
\text { Obtained }\end{array}$ & Source & $\begin{array}{c}\text { Data } \\
\text { Collection } \\
\text { Technique }\end{array}$ & $\begin{array}{l}\text { Resear } \\
\text { ch } \\
\text { Instru } \\
\text { ment }\end{array}$ \\
\hline 1 & Design & $\begin{array}{l}\text { E-Learning } \\
\text { Instructional } \\
\text { Design }\end{array}$ & $\begin{array}{l}\text { - Journals, Conference } \\
\text { Proceedings, Books, } \\
\text { Regulation } \\
\text { - Similar Institution that } \\
\text { already implemented e- } \\
\text { learning }\end{array}$ & $\begin{array}{l}\text { - Literature } \\
\text { Review } \\
\text { - Benchmarking }\end{array}$ & \\
\hline 2 & $\begin{array}{l}\text { Evaluate } \\
\text { Instructional } \\
\text { Design }\end{array}$ & $\begin{array}{l}\text { Evaluation/Valid } \\
\text { ation of e- } \\
\text { learning model } \\
\text { that have been } \\
\text { developed }\end{array}$ & Subject Matter Expert & $\begin{array}{l}\text { Focus Group } \\
\text { Discussion } \\
\text { (FGD) }\end{array}$ & $\begin{array}{l}\text { Discus } \\
\text { sion } \\
\text { Guideli } \\
\text { ne }\end{array}$ \\
\hline 3 & Develop & $\begin{array}{l}\text { Development of } \\
\text { Learning } \\
\text { Media/Material }\end{array}$ & $\begin{array}{l}\text { - Journals, Conference } \\
\text { Proceedings, Books, } \\
\text { Regulation } \\
\text { - Similar Institution that } \\
\text { already implemented e- } \\
\text { learning }\end{array}$ & $\begin{array}{l}\text { - } \text { Literature } \\
\text { Review } \\
\text { - Benchmarking }\end{array}$ & \\
\hline
\end{tabular}




\begin{tabular}{|c|c|c|c|c|c|}
\hline No & $\begin{array}{l}\text { Research } \\
\text { Phase }\end{array}$ & $\begin{array}{c}\text { Data/Information } \\
\text { Obtained }\end{array}$ & Source & $\begin{array}{c}\text { Data } \\
\text { Collection } \\
\text { Technique }\end{array}$ & $\begin{array}{l}\text { Resear } \\
\text { ch } \\
\text { Instrum } \\
\text { ent }\end{array}$ \\
\hline 4 & $\begin{array}{l}\text { Evaluate } \\
\text { Learning } \\
\text { Media }\end{array}$ & $\begin{array}{l}\text { Evaluation/Validat } \\
\text { ion of learning } \\
\text { media that have } \\
\text { been } \\
\text { developed }\end{array}$ & Subject Matter Expert & Questionnaire & \\
\hline 5 & Develop & $\begin{array}{l}\text { Learning } \\
\text { Management } \\
\text { System }\end{array}$ & $\begin{array}{l}\text { - Journals, Conference } \\
\text { Proceedings, Books, } \\
\text { Regulation } \\
\text { - Similar Institution that } \\
\text { already implemented } \\
\text { e- } \\
\text { learning }\end{array}$ & $\begin{array}{l}\text { - } \text { Literature } \\
\text { Review } \\
\text { - } \text { Benchmarkin } \\
\mathrm{g}\end{array}$ & \\
\hline 6 & $\begin{array}{l}\text { Implement } \\
\text { ation }\end{array}$ & $\begin{array}{l}\text { Achievement of } \\
\text { competence }\end{array}$ & Trainee & & \\
\hline 7 & $\begin{array}{l}\text { Evaluate } \\
\text { Training }\end{array}$ & $\begin{array}{l}\text { Evaluation of } \\
\text { competence } \\
\text { standard } \\
\text { achievement }\end{array}$ & Trainer & $\begin{array}{ll}\text { - } & \text { Assessment } \\
& \text { tools } \\
\text { - } & \text { Rubric } \\
& \text { Evaluation }\end{array}$ & \\
\hline
\end{tabular}

\section{RESULT AND DISCUSSION}

\section{A. Design}

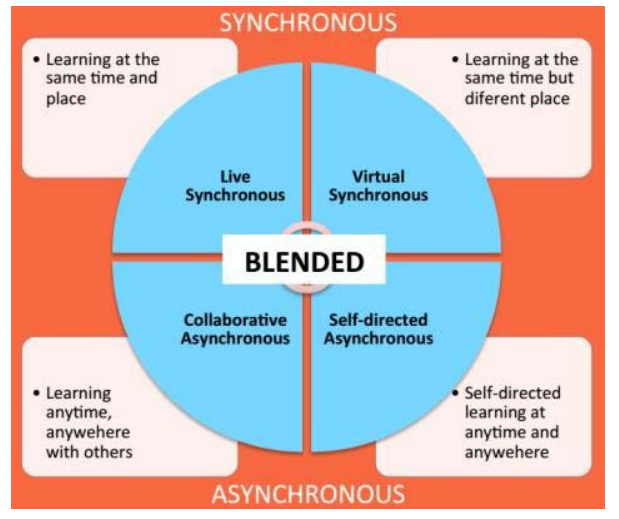

\begin{tabular}{|c|c|c|c|c|c|}
\hline \multirow[b]{2}{*}{ No } & \multirow[b]{2}{*}{ E-Learning Mode } & \multicolumn{4}{|c|}{ Learning Quadrant } \\
\hline & & $\begin{array}{c}\text { Self } \\
\text { Directed } \\
\text { Asynchro } \\
\text { nous }\end{array}$ & $\begin{array}{l}\text { Collaborati } \\
\text { ve } \\
\text { Asynchron } \\
\text { oes }\end{array}$ & $\begin{array}{c}\text { Virtual } \\
\text { Synchronous(W } \\
\text { ebinar/Video } \\
\text { Conference) }\end{array}$ & $\begin{array}{c}\text { Live } \\
\text { Synchron } \\
\text { ous (Face } \\
\text { to face) }\end{array}$ \\
\hline 1 & Adjunct & $\sqrt{ }$ & $\sqrt{ }$ & & \\
\hline 2 & Blended Learning & $\sqrt{2}$ & $\checkmark$ & $\checkmark$ & $\checkmark$ \\
\hline 3 & Fully Online Learning & $\sqrt{2}$ & $\sqrt{2}$ & $\sqrt{2}$ & \\
\hline
\end{tabular}

Figure 5. Learning quadrant mapping onto e-learning mode (modified from Chaeruman, 2017)

Based on Figure 5, researcher will construct blended learning instructional design because it consist of all 4 learning quadrant. In this instructional example, prepackaged product training will be used. The PEDATI model comprising five main steps in figure 1 will be used but we will focus more on step 3 and 4 because they were critical points in delivering online training successfully. 
The step 3 is to determine the synchronous and asynchronous learning settings. Based on the methods of Edgar Dale (1966), Smaldino (1999) and Bloom then consideration of the selection and determination of relevant learning activities can be described with question as follows:

- To achieve performance criteria or subject matter, whether it requires implementation and practice directly ? if yes, then such learning can be achieved by direct synchronous learning activity or face to face.

- If not, students simply read, hear, see, watch and participate in certain learning activities, then the learning can be achieved through asynchronous learning activities.

The example of learning activity mapping can be seen in table 3 as follows :

Table 3. Learning Activity Mapping Example

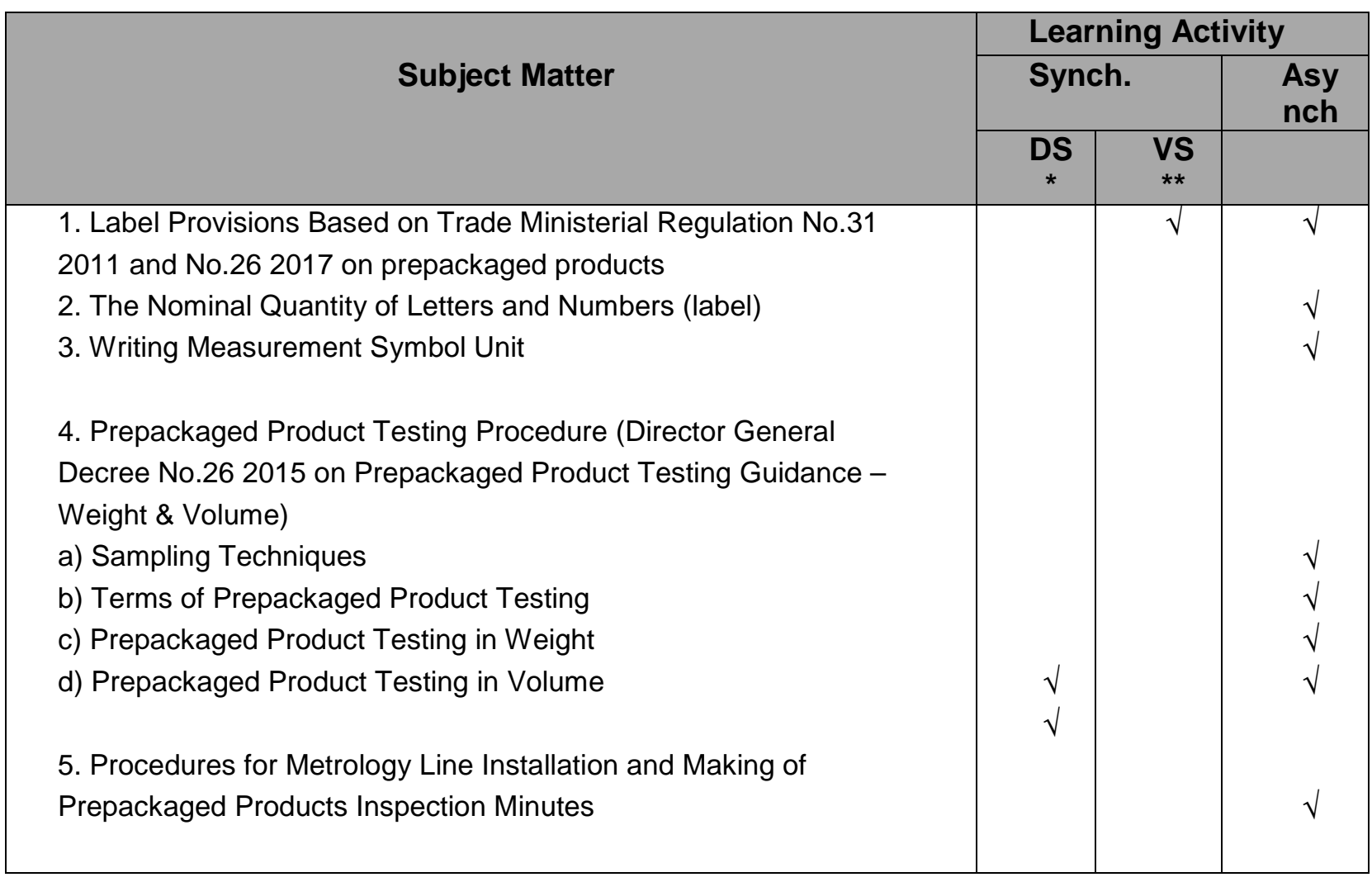

*DS $\quad$ : Direct Synchronous Learning

${ }^{*}$ VS $\quad$ : Virtual Synchronous Learning

After the learning activity is mapped, the next step is designing asynchronous learning activities, including:

1) Arrange the design of asynchronous learning activities;

Covers material, objective tests, online discussion forums and assignments as an asynchronous learning assessment. There are four things to understand: online learning path, learning object, criteria of selecting relevant media and assessment in asynchronous learning.According to selection criteria and determination of digital media / asset based on work of Merril (1998) and Smaldino (1999), digital media divided by text, audio, visual, video, animation and simulation. Each of these media are suitable to certain knowledge 
variety. For instance : to explain procedure can be delivered by text or audio, but it will be easier to understood if provided by video or animation. Last but not least are Assessment, related to what extent students master the learning achievement of competence standard that have been set. The instruments that can be used are as follows:

Non objective test: by Online discussion forums and Online Assignment Objective Test : by Multiple Choice, Matching, True/False, Short Answer.

Thus, based on these references, the design of asynchronous learning activities of subject matter 1-3 can be seen in table 4 as follows:

Table 4. Design of asynchronous learning activities

\begin{tabular}{|c|c|c|c|c|c|}
\hline \multirow{4}{*}{\multicolumn{2}{|c|}{ Subject Matter }} & \multicolumn{4}{|c|}{ Asynchronous Learning Strategy } \\
\hline & & \multicolumn{2}{|c|}{ Self Directed Asynchronous } & \multirow{2}{*}{\multicolumn{2}{|c|}{$\begin{array}{l}\text { Collaborative Asynchronous } \\
\text { Evaluation }\end{array}$}} \\
\hline & & \multirow[b]{2}{*}{ Digital Media } & \multirow[b]{2}{*}{ Test } & & \\
\hline & & & & $\begin{array}{c}\text { Online } \\
\text { Discussio } \\
\mathbf{n}\end{array}$ & $\begin{array}{c}\text { Online } \\
\text { Assignment }\end{array}$ \\
\hline 1. & $\begin{array}{l}\text { Label } \\
\text { Provisions } \\
\text { Based on Trade } \\
\text { Ministerial } \\
\text { Regulation } \\
\text { No.31 } 2011 \text { and } \\
\text { No.26 } 2017 \text { on } \\
\text { prepackaged } \\
\text { products } \\
\text { The Nominal } \\
\text { Quantity of } \\
\text { Letters and } \\
\text { Numbers (label) } \\
\text { Writing } \\
\text { Measurement } \\
\text { Symbol Unit }\end{array}$ & $\begin{array}{l}\text { 1. Video of Labelling } \\
\text { Provision based on } \\
\text { Trade Ministerial } \\
\text { Regulation No.31 } \\
2011 \text { and No.26 } \\
2017 \\
\text { 2. Presentation Slide } \\
\text { including example } \\
\text { of inspection form } \\
\text { result (ppt file) } \\
\text { 3ocument (.pdf } \\
\text { file) of } \\
\text { Trade Ministerial } \\
\text { Regulation No.31 } \\
2011 \text { and No.26 } \\
2017\end{array}$ & $\begin{array}{ll}\text { 1. } & \text { Multiple } \\
& \text { Choice } \\
\text { 2. } & \text { Labelling } \\
\text { Case } \\
\text { Study }\end{array}$ & $\begin{array}{l}\text { Analyze } \\
\text { prepackag } \\
\text { ed product } \\
\text { labelling } \\
\text { minimum } \\
\text { requireme } \\
\text { nt }\end{array}$ & $\begin{array}{l}\text { Simulating } \\
\text { prepackaged } \\
\text { product labelling } \\
\text { inspection using } \\
\text { example that } \\
\text { already been } \\
\text { set, then upload } \\
\text { the result }\end{array}$ \\
\hline
\end{tabular}

PEDATI model has not explain further about time allocated for each subject matter/learning activities. Based on class experience, for subject matter 1 to 3 , the time needed are 2, 2 and 1 Learning Hours (LH) respectively.

2) Construct an asynchronous learning pathway that includes instruction (instructional direction), description (explanation), a series of independent asynchronous activities (digital media and quizzes / tests) and a series of collaborative asynchronous activities (discussion forums and online assignments) assembled in such a way inductively or deductive into an interactive learning object, interesting and can produce the optimal learning experience possible. The learning path example of Prepackaged Product Inspection for subject matter 1-3 can be seen in table 5 as follows: 
Table 5. The learning path example of Prepackaged Product Inspection

\begin{tabular}{|c|c|c|}
\hline $\begin{array}{l}N \\
0\end{array}$ & $\begin{array}{l}\text { Event/Agen } \\
\text { da }\end{array}$ & Detailed Instruction \\
\hline 1 & Instruction & $\begin{array}{l}\text { One of the legal metrology supervisor task is prepackaged } \\
\text { product inspection which includes monitoring the suitability of } \\
\text { labeling and quantity testing. In this session we will learn about } \\
\text { the provisions of labeling based on Minister of Trade Regulation } \\
\text { No.31 } 2011 \text { and No. } 262017 \text { that previously has been read } \\
\text { through the following } \\
\text { video. Let's watch together. }\end{array}$ \\
\hline 2 & $\begin{array}{l}\text { Digital } \\
\text { Media }\end{array}$ & $\begin{array}{l}\text { The previously created Video (uploaded on YouTube) explaining } \\
\text { the labeling requirements under Minister of Trade Regulation } \\
\text { No.31 of } 2011 \text { and No.26 } 2017 \text { including the provision of letters } \\
\text { and numbers and the writing of unit symbols }\end{array}$ \\
\hline 3 & Instruction & $\begin{array}{l}\text { Is it already understood with the stipulation of prepackaged } \\
\text { labeling based on Minister of Trade Regulation No.31 } 2011 \text { and } \\
\text { No.26 } 2017 ? \text { If you are still confused please review the video or } \\
\text { discuss with the trainer or fellow training participants through the } \\
\text { following } \\
\text { discussion forum: }\end{array}$ \\
\hline 4 & $\begin{array}{l}\text { Discussion } \\
\text { Forum }\end{array}$ & $\begin{array}{l}\text { Interactive Discussion Analyze Minimum Terms that must be } \\
\text { listed } \\
\text { in the prepackaged label }\end{array}$ \\
\hline 5 & Instruction & $\begin{array}{l}\text { After studying the videos and deepening labeling through } \\
\text { discussion forums, to further internalize the labeling inspection, } \\
\text { please apply the labeling controls on the prepackaged product } \\
\text { examples around you (not necessarily the same as each } \\
\text { student). } \\
\text { Then send the results through the following task media. }\end{array}$ \\
\hline 6 & $\begin{array}{l}\text { Media } \\
\text { Assignment }\end{array}$ & Insert Assignment that accommodates students' work \\
\hline 7 & Instruction & $\begin{array}{l}\text { The final step in the series of labeling inspection is evaluation / } \\
\text { assessment. This is done through online tests of multiple choice } \\
\text { and case studies. Please do according to your understanding }\end{array}$ \\
\hline 8 & $\begin{array}{l}\text { Online } \\
\text { Assessment }\end{array}$ & $\begin{array}{l}\text { Online test is a multiple choice and case study to measure } \\
\text { students understanding toward material that has been given }\end{array}$ \\
\hline
\end{tabular}

3) Digital Media Requirement Identification

Based on learning path that already been made, the next step is identfying digital media requirements. We can see in table 6 the identification of such media for subject matter 13 as follows : 
Table 6. Digital Media Requirement Identification Example

\begin{tabular}{|c|c|c|c|c|}
\hline & Subject Matters & $\begin{array}{c}\text { Media } \\
\text { Requirements }\end{array}$ & Media Type & Total \\
\hline \multirow{9}{*}{$\begin{array}{l}1 \\
2 \\
3 . \\
3 .\end{array}$} & \multirow{9}{*}{$\begin{array}{l}\text { Label Provisions Based on } \\
\text { Trade Ministerial Regulation } \\
\text { No.31 } 2011 \text { and No.26 } 2017 \text { on } \\
\text { prepackaged products } \\
\text { The Nominal Quantity of Letters } \\
\text { and Numbers (label) } \\
\text { Writing Measurement Symbol } \\
\text { Unit }\end{array}$} & Text & $\begin{array}{l}\text { Minister of Trade } \\
\text { Regulation No.31 } 2011 \\
\text { and } 262017 \\
\text { (pdf file) }\end{array}$ & 2 \\
\hline & & Visual & $\begin{array}{l}\text { Presentation Slide } \\
\text { including example of } \\
\text { inspection form result } \\
\text { (ppt file) }\end{array}$ & 1 \\
\hline & & Audio & - & \\
\hline & & Audio-Visual & Video & 1 \\
\hline & & Animation & - & \\
\hline & & Simulation/Games & - & \\
\hline & & \multirow[t]{3}{*}{ Assessment } & Test/Quiz & 2 \\
\hline & & & Discussion Forum & 1 \\
\hline & & & Assigment & 1 \\
\hline \multicolumn{3}{|c|}{ TOTAL } & & 8 \\
\hline
\end{tabular}

After conducting identification for all subject matters, next phase is to develop digital media (i.e video). Developing digital media is discussed in the next phase.

Finishing synchronous learning activity design, we can summarize blended learning model for all subject matter from prepackaged product inspection training as illustrated in table 7:

Table 7. Blended Learning Syllabus for Prepackaged Product inspection Training

\begin{tabular}{|c|c|c|c|c|}
\hline $\begin{array}{l}\mathrm{N} \\
\mathbf{O}\end{array}$ & Subject Matter & $\begin{array}{c}\text { E-Learning } \\
\text { (LH) }\end{array}$ & $\begin{array}{c}\text { Face to Face } \\
\text { (Theory + } \\
\text { Lab } \\
\text { Work) (LH) }\end{array}$ & $\begin{array}{l}\text { Total } \\
\text { (LH) }\end{array}$ \\
\hline 1 & $\begin{array}{l}\text { Label Provisions Based on } \\
\text { Trade } \\
\text { Ministerial Regulation No.31 } 2011 \text { and } \\
\text { No.26 } 2017 \text { on prepackaged products }\end{array}$ & $\begin{array}{c}4(2 \\
\text { Asynchrono } \\
\text { us } \\
+2 \\
\text { Webinar) } \\
\end{array}$ & & 4 \\
\hline 2 & $\begin{array}{l}\text { The Nominal Quantity of Letters and } \\
\text { Numbers (label) }\end{array}$ & 2 & & 2 \\
\hline 3 & Writing Measurement Symbol Unit & 1 & & 1 \\
\hline \multirow[t]{4}{*}{4} & $\begin{array}{ll}\text { Prepackaged Product } & \text { Testing } \\
\text { Procedure (Director General } & \text { Decree } \\
\text { No.26 } 2015 \text { on Prepackaged } & \text { Product } \\
\text { Testing Guidance } & \\
\text {-Weight \& Volume) } & \\
\end{array}$ & & & \\
\hline & a. Sampling Techniques & 5 & & 5 \\
\hline & $\begin{array}{l}\text { b. Terms of Prepackaged } \\
\text { Product } \\
\text { Testing }\end{array}$ & 5 & & 5 \\
\hline & Prepackaged Product Testing in Weight & 5 & 5 & 10 \\
\hline
\end{tabular}




\begin{tabular}{|c|c|c|c|c|}
\hline No & Subject Matter & E-Learning (LH) & $\begin{array}{c}\text { Face to Face } \\
\text { (Theory + } \\
\text { Lab } \\
\text { Work) (LH) }\end{array}$ & $\begin{array}{l}\text { Total } \\
\text { (LH) }\end{array}$ \\
\hline & $\begin{array}{ll}\text { d. Prepackaged } & \begin{array}{l}\text { Product } \\
\text { Testing in }\end{array} \\
\text { Volume } & \end{array}$ & 5 & 5 & 10 \\
\hline $\begin{array}{l}5 \\
.\end{array}$ & $\begin{array}{l}\text { Procedures for Metrology } \\
\text { Installation and Making of } \\
\text { Prepackaged Products inspection } \\
\text { Minutes }\end{array}$ & 3 & & 3 \\
\hline 6 & Competence Test & & 10 & 10 \\
\hline & TOTAL & 30 & 20 & 50 \\
\hline
\end{tabular}

As shown in table 7 , blended learning model can minimize face to face learning activity from total $50 \mathrm{LH}$ ( 5 days) to only $20 \mathrm{LH}$ ( 2 days). The reduction can be more significant depending on how accurately trainer divide subject matter in to synchronous and asynchronous learning.

After designing all the stages of PEDATI model, validation through focus group discussion (FGD) among the subject matter experts are conducted with several results as follow:

1) Learning achievement in PEDATI model is fit with the title of competence unit of training.

2) Learning activity mapped correctly to divide subject matter into synchronous and asynchronous learning.

3) Determination of digital media in asynchronous learning is suitable, considering resource availability such as: time, effort and cost.

4) Need to determine time allocation for each activity in asynchronous learning (digital media, online discussion, online assignment, and online test).

5) Virtual synchronous learning activity is optional, if there is not enough resource (time, effort and costs) then we do not have to conduct such activity.

6) Need further test and trial to evaluate the design effectiveness in achieving competence standard.

\section{B. Develop}

From the design phase, we can now develop learning material based on digital media requirement identification which has been specified as example on table 8 . Video was chosen because video is playing important role on asynchronous learning, instead of telling students to read learning material that often get bored, they will get better understanding and enjoy more if they can watch the video demonstration. According to Smaldino (Smaldino \& Lowther, 2012), students' mastery of certain topics is depending on the learning experience they had. For instance, they will master $10 \%$ of the topic if they read text, $20 \%$ if they listen to lecture, $30 \%$ if they watch picture and $50 \%$ if they watch video/exhibit/demonstration on certain topic. In addition, students can rewind the video, learn according to their pace and also can watch repeatedly. Video is also more feasible and efficient in term of producing cost comparing to animation (2D/3D), augmented and virtual reality media. 


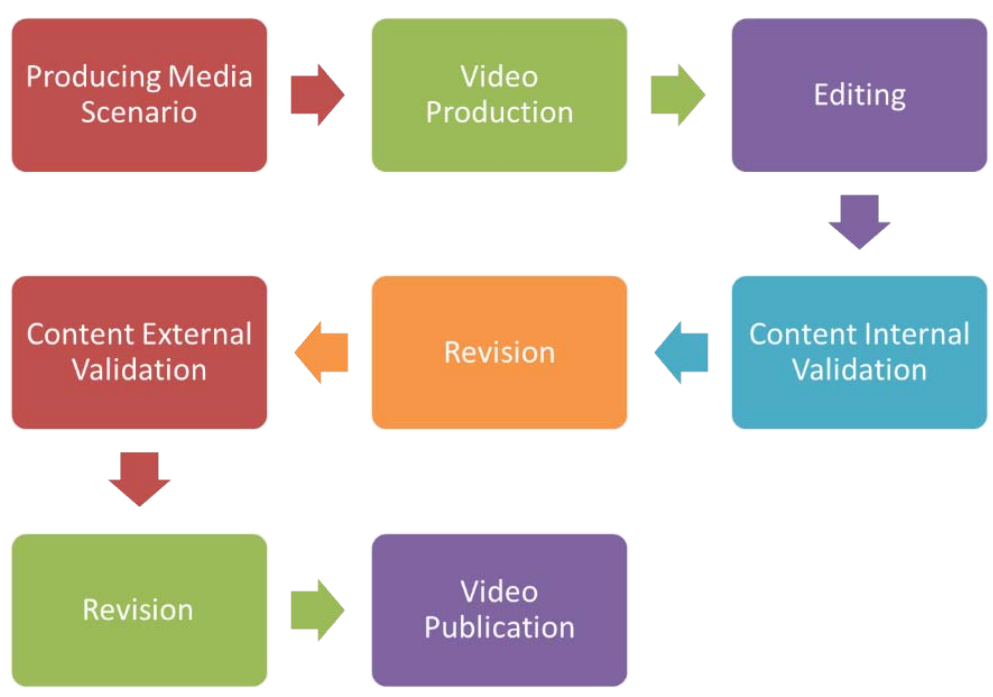

Figure 6. Development of Learning Media

The first step of learning media development as depicted in figure 6 is to produce media scenario, this part involving making step by step scene including topics, presenter narration, audio/music, scene and duration. Example of learning media scenario as presented in table 8.

Table 8. Learning Media Scenario (Example of Prepacked Product Training)

\begin{tabular}{|c|c|c|c|c|c|}
\hline No & $\begin{array}{l}\text { TOPIC } \\
\mathrm{S}\end{array}$ & PRESENTER NARRATION & $\begin{array}{l}\text { AUDIO } \\
\text { I } \\
\text { MUSIC }\end{array}$ & SCENES & DURATION \\
\hline 1 & $\begin{array}{l}\text { Openin } \\
\mathrm{g}\end{array}$ & $\begin{array}{l}\text { Presenter: } \\
\text { Ladies and Gentlemen we meet } \\
\text { again at the Prepackaged } \\
\text { Product training video learning } \\
\text { program. On this occasion a } \\
\text { Weight Prepackaged Product } \\
\text { Testing Procedure will be } \\
\text { discussed. After you see this } \\
\text { show, it is expected that you will } \\
\text { be able to carry out the testing } \\
\text { of weight prepackaged product } \\
\text { including: preparation of tools } \\
\text { and documents, Tara and } \\
\text { prepackaged product weight } \\
\text { testing based on Director } \\
\text { General Decree No. } 26 \text { of } 2015\end{array}$ & $\begin{array}{l}\text { Energi } \\
\text { zing } \\
\text { Music }\end{array}$ & $\begin{array}{ll}\text { Animation } \\
\text { 1. } & \text { Title } \\
\text { 2. } & \text { Training } \\
& \text { Subject }\end{array}$ & $5 s$ \\
\hline
\end{tabular}




\begin{tabular}{|c|c|c|c|c|c|}
\hline No & TOPICS & PRESENTER NARRATION & $\begin{array}{l}\text { AUDIO } \\
\text { I } \\
\text { MUSIC }\end{array}$ & SCENES & DURATION \\
\hline 2 & $\begin{array}{l}\text { Preparat } \\
\text { ion of } \\
\text { Tools } \\
\text { and } \\
\text { Docume } \\
\text { nt }\end{array}$ & $\begin{array}{l}\text { Presenter : } \\
\text { To conduct a weight } \\
\text { prepackage quantity testing in } \\
\text { general using testing methods } \\
\text { in a non- destructive manner, } \\
\text { the following preparation of } \\
\text { equipment is needed: } \\
\text { 1. Electronic Scales with } \\
\text { interval scales based on the } \\
\text { instructions in table } 6 . \\
\text { 2. Calculating Tool } \\
\text { (Calculator / Laptop / PC / } \\
\text { Smartphone) 3.Scissors } \\
\text { 4. Container } \\
\text { 5. Wipe Cloth / Tissue } \\
\text { The documents needed are: } \\
\text { 1. Test Form according to the } \\
\text { specified format } \\
\text { 2.ScalesCertificate } \\
\text { The next step is: } \\
\text { 1. Ensure that the scales to } \\
\text { be used have been calibrated } \\
\text { / reviewed and have a valid } \\
\text { certificate / check mark } \\
\text { 2. Setting the scales in a flat } \\
\text { state and pointing to the } \\
\text { number } 0 \text { (zero)) } \\
\text { 3. Recording prepackaged } \\
\text { data on the prepackaged } \\
\text { quantity test form. } \\
\text { 4. Determine lots for } \\
\text { inspection and determine } \\
\text { prepackaged samples. } \\
\text { 5. Determine the Maximum } \\
\text { Permissible Unit as in table } 3 .\end{array}$ & $\begin{array}{l}\text { Soft } \\
\text { Flowin } \\
\text { g } \\
\text { Music }\end{array}$ & $\begin{array}{l}\text { 1. Shows the } \\
\text { tools and } \\
\text { documents to } \\
\text { be used } \\
\text { 2. Animation } \\
\text { Table } 6 \\
\text { (transparent) } \\
\text { 3. The facilitator } \\
\text { demonstrates } \\
\text { the procedure } \\
\text { for checking } \\
\text { the scale to } \\
\text { be used and } \\
\text { sets zero } \\
\text { 4. Take note of } \\
\text { the } \\
\text { prepackaged } \\
\text { / screen } \\
\text { capture data } \\
\text { on Excel } \\
\text { 5. Determine lot } \\
\text { and sample / } \\
\text { screen } \\
\text { capture } \\
\text { provisions of } \\
\text { prepackaged } \\
\text { samples }\end{array}$ & $60 \mathrm{~s}$ \\
\hline 3 & $\begin{array}{l}\text { Tara } \\
\text { Testing }\end{array}$ & & & & $60 \mathrm{~s}$ \\
\hline 4 & $\begin{array}{l}\text { Weight } \\
\text { Prepack } \\
\text { aged } \\
\text { Testing }\end{array}$ & & & & $60 \mathrm{~s}$ \\
\hline 5 & Closing & & & & $5 \mathrm{~s}$ \\
\hline
\end{tabular}


After constructed the scenario, next phase is video production, we recruit talent and videographer from internal resources. Several equipment that we used as follow: Camera DSLR Canon D1200, Handycam, Stabilizer, Dolly, Flash, Monopod and Tripod. Video process documentary can be seen in figure 7 and 8 .
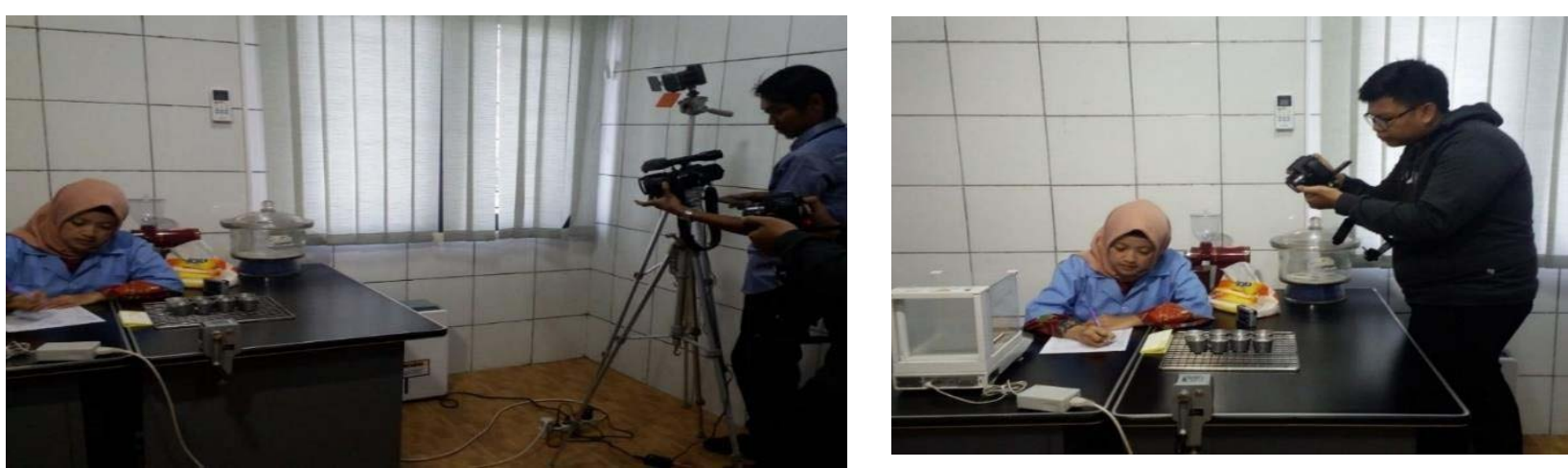

Figure 7. Behind the scenes of moisture meter video process
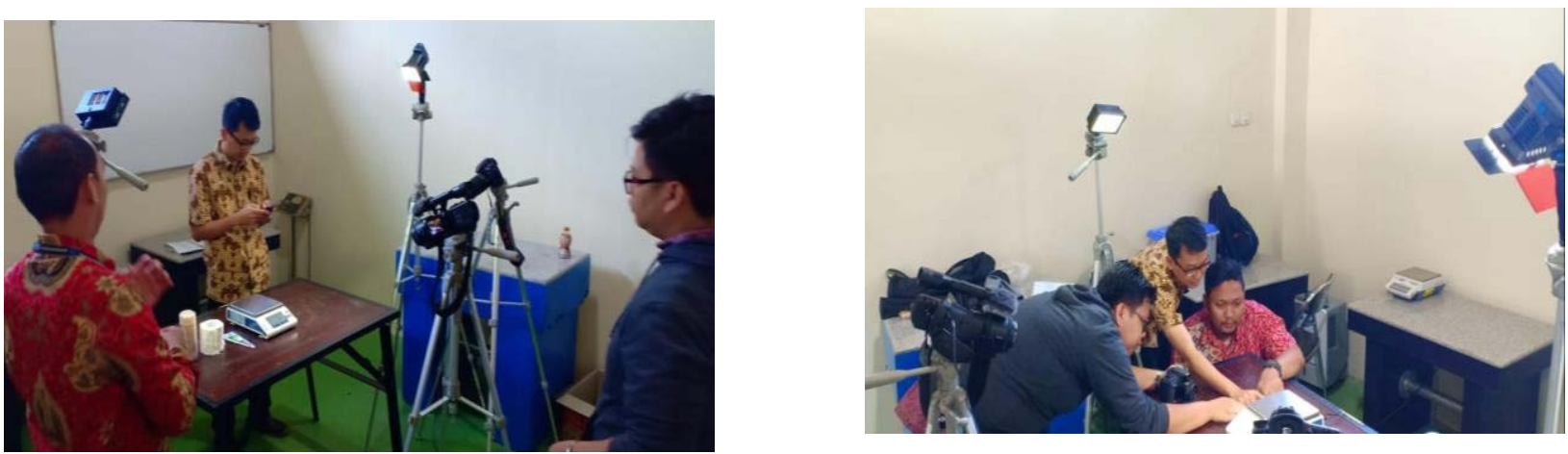

Figure 8. Behind the scenes of prepackaged video process

Finishing taking the video, we continue to add some presenter and narration in our music studio. The peripheral used such as: PC, speaker and headset monitor, mic condenser RODE, external soundcard and Studio One Application. The next step is video editing, we using Adobe Premiere to edit the video; add music, audio effects and voiceover; adjust sound and color; add titles and credits; create special effects. We can see the process in

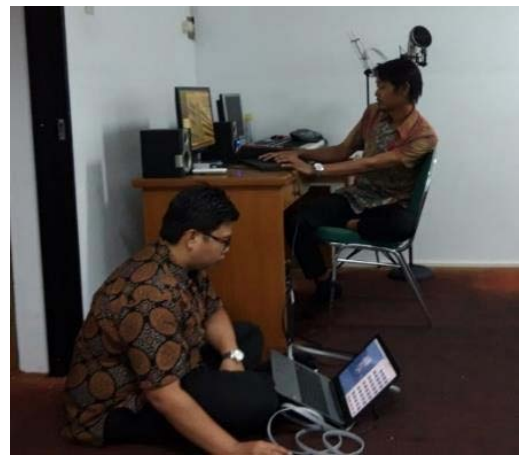

figure 9.

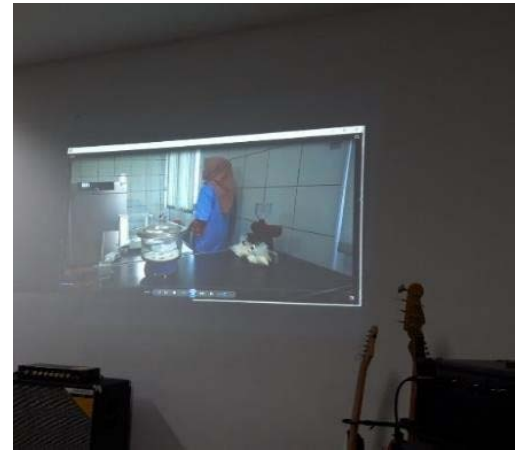

Figure 9. Editing Process

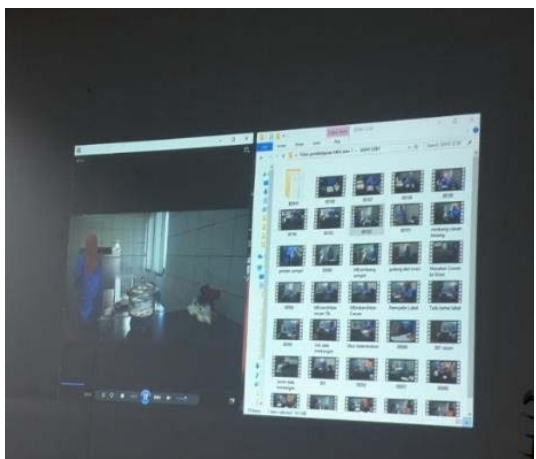


Afterwards we begin the internal content validation, this process is reviewing the video that has been edited to check its suitability with the scenario. Revision is made if necessary. Subsequently, external content validation by Subject Matter Expert was conducted in 4 criteria which is: material correctness, video quality, video duration, sound quality. The example of external content validation is as depicted in table 9.

Table 9. External content validation example on Introduction of Prepackaged Product Testing

\begin{tabular}{|c|l|c|}
\hline No & Review Criteria & Review \\
\hline 1. & Material correctness & Good \\
\hline 2. & Video Quality & Good \\
\hline 3. & Video Duration & Too Long \\
\hline 4. & Sound Quality & Unclear \\
\hline
\end{tabular}

Notes:

1. Video display : suggestions for sample images can be more varied (images can beadded not just instant noodle and $3 \mathrm{~kg}$ LPG) in minutes 04.07

2. The duration for delivery, can be shortened by 5 minutes

The external content validation are conducted on total 12 video of prepackaged product and 9 video of moisture meter. In the meantime, revision is still on progress based on input from subject matter experts. Videos that are ready for broadcast for research purposes are uploaded on Youtube Official Channel Pusat Pengembangan Sumber Daya Kemetrologian as illustrated in figure 10.

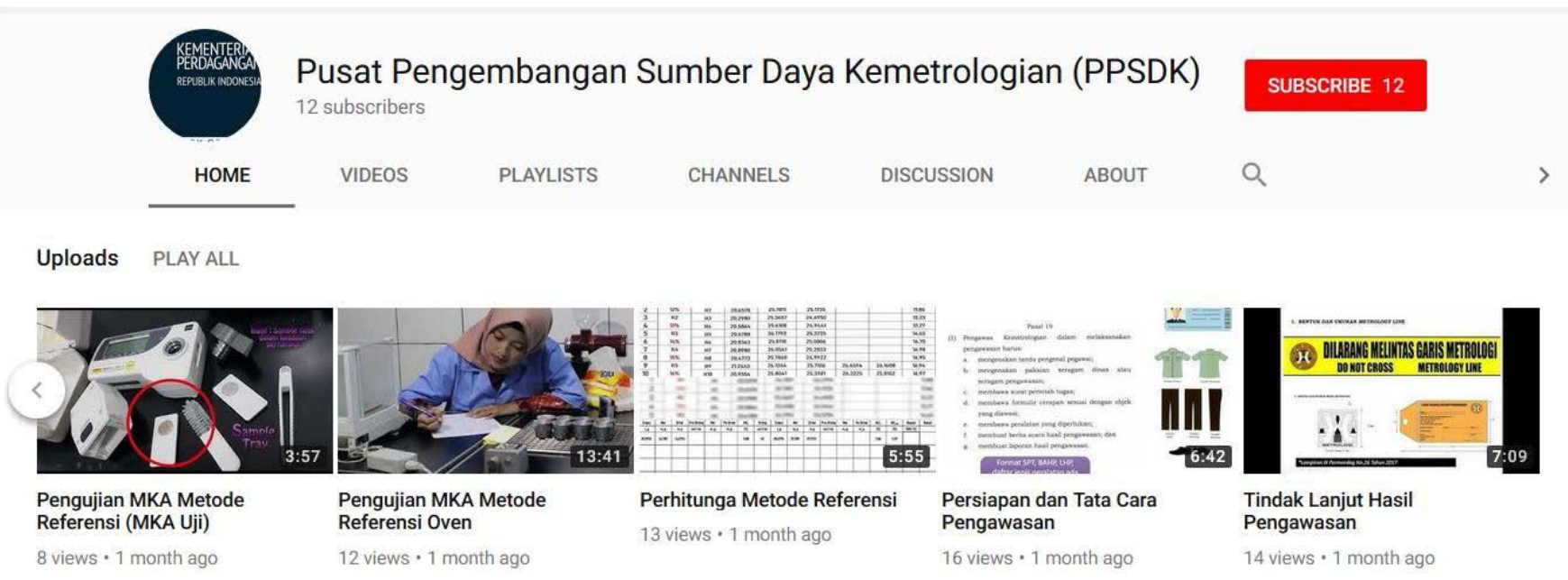

Figure 10. Officiant Channel of Pusat Pengembangan Sumber Daya Kemetrologian on Youtube 
YouTube was chosen because its characteristic which is : free, unlimited storage, secure, high availability and abundance of free quota promotion using Indonesia GSM Provider.

The $2^{\text {nd }}$ part of is to develop learning management system (LMS) that will be used to administer and organize online learning. First thing to do is to map e-learning process cycle onto LMS function to see its compatibility. We can notice the mapping table 10.

Table 10. E-learning process cycle mapping onto LMS Function

\begin{tabular}{|l|l|l|}
\hline No & E-Learning Process Cycle & LMS Function \\
\hline 1 & Pelajari : pdf, ppt, video, animation & Upload and Sharing Material \\
\hline 2 & $\begin{array}{l}\text { Dalami : Discussion Forum, Chat, Video } \\
\text { Conference }\end{array}$ & Forum and Chat \\
\hline 3 & Terapkan : Self \& Group Assignment & Gathering and View Assignment \\
\hline 4 & Evaluasi : Quiz \& Competence Test & Quiz \\
\hline & & Recording Grade \\
\hline & & User Management \\
\hline
\end{tabular}

From table 10 we can conclude that all e-learning process cycle can be facilitated by LMS Function. The next step is to choose the most suitable LMS to be implemented in MRDC. We compare pros and cons from 3 types of LMS as conceived in table 11.

Table 11. Comparison from 3 types of LMS

\begin{tabular}{|c|c|c|c|c|}
\hline No & LMS Type & Example & Pros & Cons \\
\hline 1 & Proprietary & $\begin{array}{l}\text { Wordpress LMS, Joomla } \\
\text { LMS, Blackboard, dll }\end{array}$ & $\begin{array}{l}\text { - Reliable and Functional } \\
\text { - Training \& Support }\end{array}$ & $\begin{array}{l}\text { Prices are relatively expensive } \\
\text { for application fees, hosting, } \\
\text { maintenance and technical } \\
\text { support } \\
\text { - Relatively difficult to customize }\end{array}$ \\
\hline 2 & Open Source & Moodle, Atutor, Sakai, dll & $\begin{array}{l}\text { - Free / Freemium } \\
\text { - Easy to use and customized }\end{array}$ & $\begin{array}{l}\text { Development of features } \\
\text { depends on the community } \\
\text { - Hidden Cost: Hosting costs, } \\
\text { Maintenance, Backup, Extra } \\
\text { Storage and Technical Support }\end{array}$ \\
\hline 3 & $\begin{array}{l}\text { Cloud Based } \\
\text { LMS }\end{array}$ & $\begin{array}{l}\text { Ruang Guru, Kelase, } \\
\text { Edmodo, Google } \\
\text { Classroom, dll }\end{array}$ & $\begin{array}{l}\text { - Free and or relatively } \\
\text { inexpensive costs } \\
\text { - Pay as you go } \\
\text { - Many features (customize by } \\
\text { customer) } \\
\text { - Scalable } \\
\text { - No need for hosting investment } \\
\text { or technical support }\end{array}$ & $\begin{array}{l}\text { - Some have weaknesses in data } \\
\text { security }\end{array}$ \\
\hline
\end{tabular}

Source : Compiled from various sources and benchmarking 
In the selection of the LMS, the first thing to consider is how the LMS will be able to meet user needs (at least it must be able to fulfill the LMS function). After the LMS feature is identified, the next step is to determine which LMS to choose, of course based on various factors such as system requirements and available IT resources (including budget, IT human resources, server availability, bandwidth, etc.).

From our benchmarking result which can be seen in table 12, we can summarize that 4 from 5 institution using Moodle (open source) as their LMS platform, only 1 institution using proprietary LMS which is WordPress LMS. It makes sense because Moodle and WordPress LMS can fulfill their requirement and they have all the IT Resources to implement and maintain that system.

Table 12. Benchmarking Result of LMS Platform used in several training/highereducation institutions

\begin{tabular}{|c|c|c|c|c|c|}
\hline $\begin{array}{l}\mathbf{N} \\
\mathbf{0}\end{array}$ & Institution & $\begin{array}{l}\text { URL E- } \\
\text { Learnin } \\
\text { g }\end{array}$ & $\begin{array}{c}\text { LMS } \\
\text { Platform }\end{array}$ & $\begin{array}{l}\text { Impleme } \\
\text { ntation } \\
\text { Mode }\end{array}$ & IT Resources \\
\hline 1 & $\begin{array}{l}\text { Politeknik } \\
\text { Negeri } \\
\text { Bandung }\end{array}$ & $\begin{array}{l}\frac{\text { http://e- }}{\text { learning }} \\
\text { olp } \\
\text { olban.a } \\
\text { c.i d/ }\end{array}$ & Moodle & Optional & $\begin{array}{l}\text { - IT Staff : Programmer, Network } \\
\text { Administrator and Technical } \\
\text { Support } \\
\text { - Server } \\
\text { - Network Operation Center } \\
\end{array}$ \\
\hline 2 & $\begin{array}{l}\text { Politeknik } \\
\text { Manufaktur } \\
\text { Bandung }\end{array}$ & $\begin{array}{l}\frac{\text { http://el }}{\text { ear }} \\
\frac{\text { ning.pol }}{\text { m an- }} \\
\frac{\text { bandun }}{\text { g.a }} \\
\frac{\text { c.id } /}{}\end{array}$ & Moodle & Optional & $\begin{array}{l}\text { - IT Staff : Programmer, Network } \\
\text { Administrator and Technical } \\
\text { Support } \\
\text { - Server } \\
\text { - Network Operation Center }\end{array}$ \\
\hline 3 & $\begin{array}{l}\text { Politeknik } \\
\text { Elektronika } \\
\text { Negeri } \\
\text { Surabaya }\end{array}$ & $\begin{array}{l}\frac{\text { http://el }}{\text { ear }} \\
\frac{\text { ning.pe }}{\text { ns. }} \\
\text { ac.id/ }\end{array}$ & Moodle & $\begin{array}{l}\text { Required } \\
\text { for } \\
\text { distance } \\
\text { learning, } \\
\text { optional } \\
\text { for } \\
\text { regular }\end{array}$ & $\begin{array}{l}\text { - IT Staff : Programmer, Network } \\
\text { Administrator and Technical } \\
\text { Support } \\
\text { - Server } \\
\text { - Network Operation Center }\end{array}$ \\
\hline 4 & $\begin{array}{l}\text { Balai } \\
\text { Pendidikan } \\
\text { dan } \\
\text { Pelatihan } \\
\text { Teknologi } \\
\text { Informasi \& } \\
\text { Komunikasi }\end{array}$ & & Moodle & Opsional & $\begin{array}{l}\text { - IT Staff : Programmer, Network } \\
\text { Administrator and Technical } \\
\text { Support } \\
\text { - Server } \\
\text { - Network Network Operation Center }\end{array}$ \\
\hline 5 & $\begin{array}{l}\text { Badan Diklat } \\
\text { Keuangan }\end{array}$ & $\frac{\frac{\text { https:// }}{\text { klc. }}}{\frac{\text { kemen }}{\text { keu }}}$ & $\begin{array}{l}\text { Wordpre } \\
\text { ss LMS }\end{array}$ & $\begin{array}{l}\text { Blended } \\
\text { Learning }\end{array}$ & $\begin{array}{l}\text { - IT Staff : Programmer, Network } \\
\text { Administrator and Technical } \\
\text { Support } \\
\text { - Server } \\
\text { - Network Operation Center }\end{array}$ \\
\hline
\end{tabular}

Source: (Wicaksono Febriantoro, 2018) 
Differ from those benchmarking result, MRDC doesn't have adequate IT Resources such as IT Staff, Network Operation Center, etc. Those IT Resources are required in installation, hosting and conduct regular maintenance (technical support). We only have some servers with limited bandwidth. Consequently, the choice is pursed on Cloud Based LMS such as: Ruang Guru, Kelase, Edmodo and Google Classroom. They all offered free or relatively inexpensive cost, many features, scalable and the most important one is no need of hosting investment and technical support. MRDC can focus on conducting and developing e-learning program and not mess around with the configuration and maintenance of information technology devices. For this research we choose to use Kelase with several consideration:

1 Complete features ranging from registration, management of learning (teaching materials, forums, assignments, etc.), online quizzes, grades management and reports on learning outcomes

2 Free Trial 1 year of Kelase Pro Version (https://ppsdkkemendag.kelase.id )

3. One of the best clouds based LMS made in Indonesia that has been used by various agencies.

However, this choice can vary between agencies, according to our experience and some input from e-learning experts, it doesn't matter of what LMS platform that your institutions used. As long as it can meet your requirement and comfortable to use among the user (trainer/lecturer/teacher, student/training participants and training organizer). Example of learning activities in kelase are depicted in figure 11.

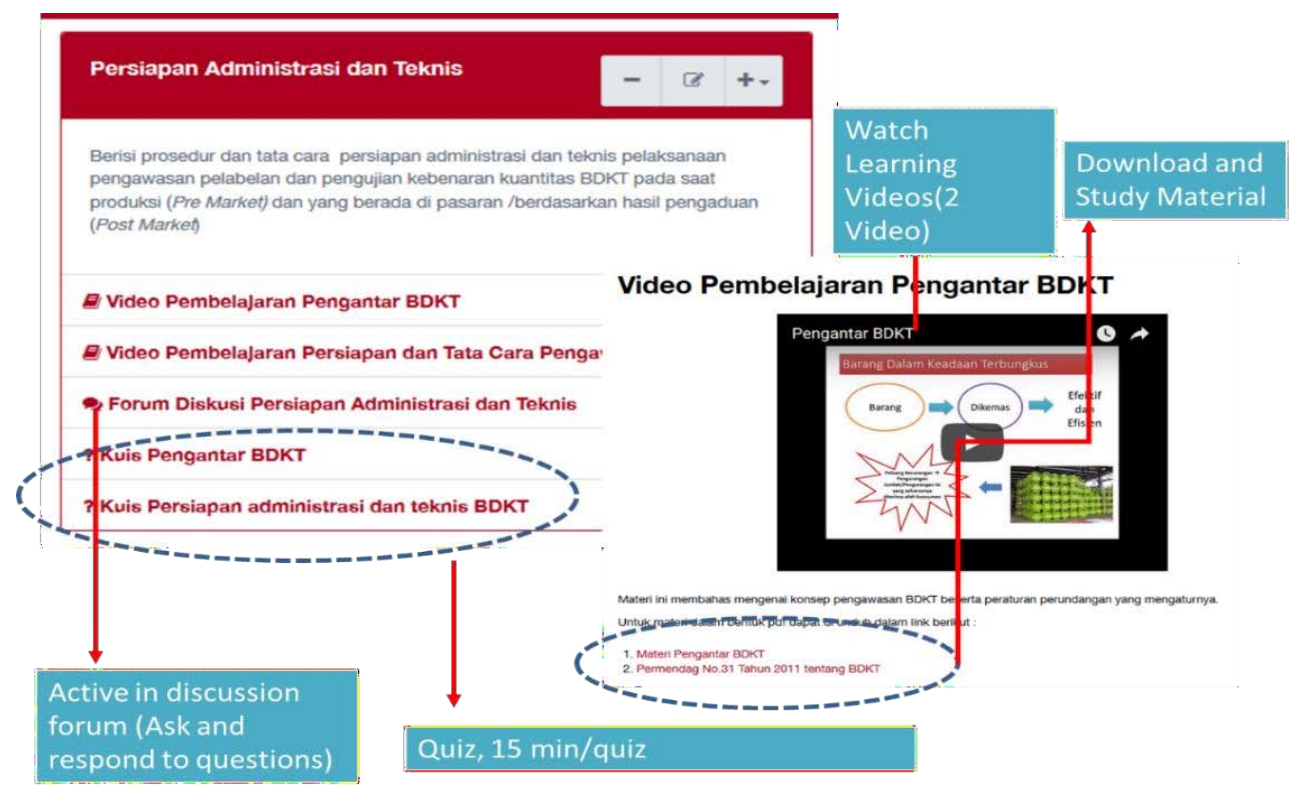

Figure 11. Example of learning activities in Kelase 


\section{Implementation and Evaluation}

To see the effectiveness of design and material development in adjunct, blended and fully learning models on metrological training, then we carried out e-learning training. For the adjunct model, an analysis of pre-learning activities which is carried out in the metrological functional training. Two trainings, namely verification of moisture meters and prepackaged product inspection training for blended and fully.

In this study, the selection of informants for functional training was the second functional training participants of 2018. Informants of metrological technical training, moisture meters and prepackaged product inspection training, was determine based on location of legal metrology unit, formal education level, year of graduation of functional training, position at office and potential of specified measuring instrument.

Based on the questionnaire results on the readiness of participants in implementing e- learning, with a scale value of 1 to 5 , show that the readiness of participants to form e-learning training is at number 4 (ready to implement). This questionnaire includes personal readiness from impartial training, supporting facilities (laptops, smartphones and internet facilities).

As stated before, Kelase, was the chosen LMS. Registration of participant using google form and all the communication during the process using WhatsApp group. Table 13 is the summary of the training:

Table 13. Implementation of E-learning Metrological Training Scheme

\begin{tabular}{|l|c|c|c|}
\hline & $\begin{array}{c}\text { Metrological } \\
\text { Functional Training }\end{array}$ & $\begin{array}{c}\text { Prepackaged } \\
\text { Product Inspection } \\
\text { Training }\end{array}$ & $\begin{array}{c}\text { hoisture Meters } \\
\text { Training }\end{array}$ \\
\hline Learning Model & Adjunct & Blended and Fully & Blended and Fully \\
\hline Time Schedule & 1 week & 2 weeks & 2 weeks \\
\hline $\begin{array}{l}\text { Formal } \\
\text { Education } \\
\begin{array}{l}\text { Background of } \\
\text { Participants }\end{array}\end{array}$ & $\begin{array}{c}\text { Diploma and } \\
\text { undergraduate }\end{array}$ & $\begin{array}{c}\text { Senior High School } \\
\text { and undergraduate }\end{array}$ & $\begin{array}{c}\text { Diploma and } \\
\text { undergraduate }\end{array}$ \\
\hline $\begin{array}{l}\text { Location of } \\
\text { participant }\end{array}$ & Indonesia & $\begin{array}{c}\text { Kalimantan, } \\
\text { Sumatera, Papua }\end{array}$ & Sulawesi, Jawa \\
\hline
\end{tabular}

In the initial scheme of the implementation of the two e-learning trainings, we prepared a training schedule limited by learning sessions. Firstly, to enter the session the participants must have completed one session and so on until all learning sessions are completed. Secondly, after being evaluated on the progress of learning, this session system cannot be applied to metrological e-learning training, this is due to the 
characteristics of the work performed in metrology. The majority of participants spend their work time in the field or on the way to the location of verification or inspection. Although learning materials can be accessed anywhere but participants find it difficult to concentrate if they have to spend time learning while working on verification and inspection

Based on this, we have carried out two training schemes. Prepackaged Product Inspection Training uses a scheme that is limited by learning sessions while Moisture Meters Training is not limited by learning sessions. From the results of the implementation evaluation, limiting the learning session will make it easier for instuctor and training manager to control the training process. And vice versa for e-learning training that is not limited by learning sessions, in this form the instructor and manager of the training must be more active in controlling the training process and checking the progress of the learning participants.

In metrological functional training, e-learning conducted in the beginning of the learning process, named pre-learning, consist of 9 lessons. Participant, still on their hometown while doing e-learning. Mostly, they have no experiences before. Accordingly, the goals of this prelearning programmed was to introduce all the lesson that they will get on the face to face session. There is a positive correlation on the activity of participants in pre-learning activities with the final results of face-to-face learning. Participant that completed all the lesson on prelearning show good performance. Achievement in metrological functional training on average for cognitive competencies is 80 and for psychomotor competencies is 80 .

In technical metrological training, two types of training have been prepared. These two types of training are distinguished from the participants' backgrounds. Prepackaged product inspection training for inspection officer and moisture meter training for verification officer. This difference in the background of participants is an interesting thing to study in terms of activeness in completing e-learning training and the achievement of learning competencies. Interesting things encountered in prepackaged product inspection training are the best achievements for learning competencies (cognitive and psychomotor) achieved by participants with high school formal education background. This shows the absence of significant obstacles from the level of formal education of participants to achieve learning competencies through e- learning training. Achievement in metrological technical training on average for cognitive competencies is 80 and for psychomotor competencies is 70 .

There are differences in the achievement of psychomotor competencies in metrological functional training and metrological technical training. This shows that the achievement of psychomotor competency will be better if done directly in the form of face to face. So, in the implementation of metrological technical training, the blended learning model is mo 
appropriately applied. For metrological fully online training can be applied to refreshment forms of training. In those training, participant is not in full learning of new things but more about repetition and recalling what has been learned.

Various aspects that influence the success in implementing e-learning include commitment, age of participants, mastery of technology and other routine office work. Commitment plays a very big role in the success of e-learning training, this is still lacking in training participants. One obstacle to commitment is the assumption that e-learning will replace conventional training and technical training is difficult to implement with e-learning. Older participants find it difficult to attend online training in terms of technical skills in mastering IT technology. Participants found difficulty in dividing the time between routine work and time to do online learning. Therefore, it requires special commitment from the office managers to give some time in working hours to complete online tasks.

\section{CONCLUSION AND SUGGESTION}

E-learning based metrological training analysis has been conducted to find the most suitable training model. The design of e-learning carried out in the form of adjunct, blended learning and fully online. Firstly, Learning design has been developed in the form of Training Design (RBDP). One of Training Design used in this research is PEDATI Model which after been validated by subject matter expert, it can be used to implement metrological training through e-learning. Precise learning activity mapping into synchronous and asynchronous learning can make sure the achievement of competence standard and in the same time reducing time needed to conduct face to face learning. It's carried out both for metrological functional and metrological technical training. Secondly, the development of online learning media using video. Video was selected because video is playing pivotal role on asynchronous learning, instead of telling students to study learning material that often get bored, they will get better comprehension and relish more if they can watch the video demonstration. Thirdly, the development of the Learning Management System (LMS) model carried out by comparing 3 types of LMS which is proprietary, open source and cloud based LMS and also by conducting benchmark of e- learning platform used in several education and training institution. Based on e-learning process cycle requirement and MRDC IT Resources availability (IT Staff, Server, Network Operation Center, etc.) at the moment the choice is pursed on Cloud Based LMS which is Kelase. With cloud based LMS, MRDC can focus on conducting and developing e-learning program and not bothered with the configuration and maintenance of information technology devices. Nevertheless, this choice 
can vary between agencies, as long as the LMS can meet the requirement and comfortable to use among the user (trainer/lecturer/teacher, student/training participants and training organizer) it will be fine to be used.

To analyze the achievement of cognitive and psychomotor competencies, a simulation of learning design (RBDP) has been conducted and an evaluation of the e-learning training simulation held. Achievement in metrological functional training on average for cognitive competencies is 80 and for psychomotor competencies is 80 . Whereas, achievement in metrological technical training on average for cognitive competencies is 80 and for psychomotor competencies is 70 . Therefore, in the implementation of metrological technical training, blended learning model is more appropriately applied. For metrological fully online training can be applied to refreshment forms of training. In those training, participant is not in full learning of new things but more about repetition and recalling what has been learned.

Future research can be done in the area of pre, in and post e-learning based training. Parallel to them, development of learning media such as: video, stop motion, 2D/3D animation, augmented and virtual reality need to be explored more deeply in order to support e-learning content effectively. 


\section{REFERENCES}

\section{Books}

Bloom, B. S., \& Engelheart, M. D. (1956). Taxonomy of educational objectives: The classification of educational goals. Handbook I: Cognitive domain. New York: David McKay Company.

Dale, E. (1969). Audiovisual methods in teaching.

Donald, C. R. (1999). Bloom's Taxonomy of Learning Domains.

Horton, W. (2006). e-Learning by Design. USA: John Willey and Son.

Kemp, J. E., Morrison, G. R., \& Ross, S. (1994). Designing Effective Instruction. New York: MacMillan College Publ.Co.

Mager, R. F. (1984). Developing Attitude Toward Learning (2nd ed.). Atlanta: GA: The Center for Effective Performance Inc.

Smaldino, S. E., \& Lowther, D. L. (2012). Instructional Technology \& Media for Learning. Jakarta: Kencana.

Sugiyono. (2015). Metode Penelitian \& Pengembangan. Alfabeta.

Walter, D., Carey, L., \& Carey, J. O. (2005). The Systematic Design of Instruction (6th edition).

Boston: MA : Pearson.

\section{Journals/ Proceedings/ Dissertations/ Theses}

Alammary, A., Sheard, J., \& Carbone, A. (2014). Blended learning in higher education: Three different design. Australasian Journal of Educational Technology.

Chaeruman, U. A. (2012). Blended Learning : A Framework Model for Lecturer. International Symposium of Open, Distance and e-Learning. Bali.

Chaeruman, U. A. (2013). Merancang Blended Learning yang membelajarkan. Seminar Nasional "Meningkatkan Kualitas Pembelajaran Melalui Sumber-Sumber dan Teknologi yang Tepat". Surakarta: UNS.

Chaeruman, U. A. (2017). PEDATI Model Desain Sistem Pembelajaran Blended. Panduan Merancang Mata Kuliah Daring SPADA Indonesia. Direktorat Pembelajaran, Dirjen Pembelajaran dan Kemahasiswaan, Kemenristekdikti.

Chaeruman, U. A., Wibawa, B., \& Syahrial, Z. (2017). Blended Learning System Design Model.

Third International Conference on Innovation in Education - ICIE . Bangkok: Mahidol University.

Mabed, M., \& Koehler, T. (2012). An Instructional Design for Developing an Effective Blended Learning Environment. EDULEARN12 Conference. Barcelona.

Noirid, S. (2007). E-Learning Models : A Review of Liteature. The 1st International Conference on Education Reform. Thailand: Mahasarakham University.

Prayitno, W. (2015). Implementasi Blended Learning dalam Pembelajaran pada Pendidikan Dasar dan Menengah. Jurnal Pendidikan, Volume VI No.01.

Wicaksono Febriantoro, R. H. (2018). PERANCANGAN BLENDED LEARNING SYSTEM DALAM MENDUKUNG COMPETENCE BASED TRAINING (CBT) SDM

KEMETROLOGIAN. Jurnal Insan Metrologi. 


\section{Others}

Stockley, D. (n.d.). e-Learning Definition and Explanation. Retrieved January 21, 2018, from http://www.derekstockley.com.au/elearning-definition.html

\section{ABOUT THE AUTHORS}

Suci Ingrid Daniati : Trainer, Metrological Resources Development Centre, Ministry of Trade, Bandung, Indonesia

Wicaksono Febriantoro : Trainer, Metrological Resources Development Centre, Ministry of Trade, Bandung, Indonesia 